\title{
Collagen Biosynthesis
}

\author{
CHARACTERIZATION OF SUBCELLULAR FRACTIONS FROM EMBRYONIC \\ CHICK FIBROBLASTS AND THE INTRACELLULAR LOCALIZATION OF \\ PROTOCOLLAGEN PROLYL AND PROTOCOLLAGEN LYSYL HYDROXYLASES
}

\author{
By RICHARD HARWOOD, MICHAEL E. GRANT and DAVID S. JACKSON \\ Department of Medical Biochemistry, The Medical School, University of Manchester, \\ Oxford Road, Manchester M13 9PT, U.K.
}

(Received 7 June 1974)

\begin{abstract}
1. Subcellular fractions of freshly isolated matrix-free embryonic chick tendon and sternal cartilage cells have been characterized by chemical analysis, electron microscopy and the location of specific marker enzymes. These data indicate the fractions to be of a high degree of purity comparable with those obtained from other tissues, e.g. liver and kidney. 2. When homogenates were assayed for protocollagen prolyl hydroxylase and protocollagen lysyl hydroxylase activities, addition of Triton $\mathrm{X}-100(0.1 \%, \mathrm{w} / \mathrm{v})$ was found to stimulate enzyme activities by up to $60 \%$ suggesting that the enzymes were probably membrane-bound. 3. Assay of subcellular fractions obtained by differential centrifugation for protocollagen prolyl hydroxylase activity indicated the specific activity to be highest in the microsomal fraction. Similar results were obtained for protocollagen lysyl hydroxylase activity. 4. Submicrosomal fractions obtained by discontinuous sucrosegradient centrifugation were assayed for the two enzymes and protocollagen prolyl hydroxylase and protocollagen lysyl hydroxylase were found to be associated almost exclusively with the rough endoplasmic reticulum fraction in both tendon and cartilage cells.
\end{abstract}

The hydroxyproline and hydroxylysine residues in collagen are synthesized by the enzymic hydroxylation of appropriate proline and lysine residues subsequent to their incorporation into peptide linkages (for review see Grant \& Prockop, 1972a,b,c). These post-translational events require two separate enzymes, protocollagen prolyl hydroxylase and protocollagen lysyl hydroxylase.

Early work suggested that the prolyl hydroxylase was located in a microsomal fraction prepared from chick embryos (Peterkofsky \& Udenfriend, 1965), but subsequent studies suggested that essentially all the enzymic activity was found in the cytosol fraction of chick embryo homogenates and only a small part of the total activity was recovered in the microsomal or other particulate fractions (Kivirikko \& Prockop, 1967). This latter result suggested that the enzyme was not membrane-bound, but its intracellular location was not established. More recent studies on the lysyl hydroxylase have suggested that it too might be a soluble protein but only $63 \%$ of total enzyme activity in a chick embryo homogenate was associated with the soluble protein fraction (Kivirikko \& Prockop, 1972). Whether or not the remaining activity was trapped or directly associated with the particulate fractions was not ascertained and because of inherent difficulties in homogenizing connective tissues, the intracellular location of this enzyme has not been established.
To determine the intracellular sites of the various post-translational events which occur during the biosynthesis of the collagen precursor procollagen (for review see Schofield \& Prockop, 1973) we have undertaken a characterization of subcellular fractions from freshly isolated matrix-free embryonic chick fibroblasts and we have determined the distribution of protocollagen prolyl hydroxylase and protocollagen lysyl hydroxylase in these fractions. A preliminary report of part of this work has been presented elsewhere (Harwood et al., 1974b).

\section{Experimental}

\section{Materials}

Fertile eggs obtained from Mytholmroyd Hatcheries, Hebden Bridge, Yorks., U.K. were incubated for 17 days at $37^{\circ} \mathrm{C}$ in a moist atmosphere in a Westernette Egg Incubator (Western Incubators Ltd., Chelmsford, Essex, U.K.). $\left[5^{-3} \mathrm{H}\right]$ Proline $(10 \mathrm{Ci} / \mathrm{mmol})$ and $\left[4,5-{ }^{3} \mathrm{H}\right] \mathrm{lysine}(5.3 \mathrm{Ci} / \mathrm{mmol})$ were purchased from The Radiochemical Centre, Amersham, Bucks., U.K. Trypsin solution, $2.5 \%$ in $0.15 \mathrm{M}$ $\mathrm{NaCl}$, Eagle's Basal Medium with Earle's Salts, and foetal calf serum were purchased from Flow Laboratories, Irvine, Ayrshire, U.K. Collagenase [171 Pzunits (Wünsch \& Heidrich, 1963)/mg] was obtained from Serva Fine Biochemicals, Heidelberg, Germany 
and $\alpha \alpha^{\prime}$-bipyridyl was obtained from Calbiochem, Los Angeles, Calif., U.S.A. Cycloheximide, UDP, p-nitrophenyl phosphate, sodium succinate and bovine serum albumin were all obtained from Sigma Chemical Co., London S.W.6, U.K. Calf thymus DNA and Triton X-100 (scintillation grade) were supplied by Koch-Light Laboratories Ltd., Colnbrook, Bucks., U.K. All other chemicals were supplied by British Drug Houses Ltd., Poole, Dorset, U.K. and were of AnalaR grade wherever available.

\section{Preparation and subcellular fractionation of cells}

Isolation of matrix-free cells. Cells were isolated from the leg tendons and sterna of 17-day chick embryos by digestion with trypsin and partially purified collagenase under conditions similar to those described by Dehm \& Prockop (1971, 1972, 1973). In most experiments $12 \times 10^{6}-20 \times 10^{6}$ cells were obtained from the tendons of a single embryo and approx. $4 \times 10^{6}-6 \times 10^{6}$ cartilage cells were obtained per sternum.

Homogenization and fractionation of cells. Matrixfree cells were resuspended in $0.25 \mathrm{M}$-sucrose in $0.05 \mathrm{M}$ Tris- $\mathrm{HCl}$ buffer, $\mathrm{pH} 7.5$, containing $0.025 \mathrm{M}-\mathrm{KCl}$ and $0.5 \mathrm{mM}-\mathrm{MgCl}_{2}$. The suspension was homogenized with 25 strokes at speed-setting seven of a motordriven glass-Teflon Potter-Elvehjem homogenizer (Tri-R Instruments Inc., New York, U.S.A.) of $15 \mathrm{ml}$ capacity and $0.9-1.5 \mathrm{~mm}(0.004-0.006$ inches) clearance. The homogenization of single-cell suspensions can prove particularly difficult (Avis, 1972) and to obtain optimal results it was necessary to use small volumes, high cell concentrations $\left(6 \times 10^{7}-8 \times 10^{7}\right.$ cells $/ \mathrm{ml}$ ) and to monitor closely the degree of cell breakage by microscopic examination. The homogenization and all subsequent centrifugation procedures were carried out at $4^{\circ} \mathrm{C}$.

Subcellular fractions were obtained by two different schemes. By differential centrifugation, the homogenate was initially centrifuged at $600 \mathrm{~g}$ for $5 \mathrm{~min}$ in a Mistral $6 \mathrm{~L}$ centrifuge to sediment nuclei and cell debris. The nuclear pellet was resuspended in $2.5-5.0 \mathrm{ml}$ of the above sucrose-Tris- $\mathrm{KCl}-\mathrm{MgCl}_{2}$ buffer and rehomogenized with 10 strokes at speedsetting 7. This homogenate was resedimented at $600 \mathrm{~g}$ for $5 \mathrm{~min}$ to yield the nuclear fraction $(\mathrm{N})$ and a supernatant which was pooled with the first postnuclear supernatant. A mitochondrial fraction (ML) was obtained by centrifugation of the pooled supernatants at $10000 \mathrm{~g}\left(r_{\mathrm{av}} .6 .5 \mathrm{~cm}\right)$ for $10 \mathrm{~min}$ in the $10 \times 10 \mathrm{ml}$ titanium angle rotor of an MSE Superspeed 65 ultracentrifuge. The postmitochondrial supernatant was centrifuged at $105000 \mathrm{~g}\left(r_{\mathrm{av}} .6 .5 \mathrm{~cm}\right)$ for $1 \mathrm{~h}$ in the above rotor to yield a microsomal pellet (M) and the cytosol fraction (C).

To achieve a separation of rough endoplasmic reticulum from smooth endoplasmic reticulum a discontinuous sucrose-density-gradient technique was used. Cells were homogenized in $0.25 \mathrm{M}$-sucrose in water and the centrifugation and rehomogenization of the first nuclear pellet were carried out as described above. The mitochondrial fraction was sedimented at $10000 \mathrm{~g}$ for $10 \mathrm{~min}$, the postmitochondrial supernatant was adjusted to $15 \mathrm{~mm}-\mathrm{CsCl}$, and the resulting suspension was layered over $1.3 \mathrm{M}$-sucrose containing $15 \mathrm{~mm}-\mathrm{CsCl}$, as described by Dallner (1963). After centrifugation at $105000 \mathrm{~g}\left(r_{\text {av }} .6 .9 \mathrm{~cm}\right)$ for $3 \mathrm{~h}$ in the $8 \times 25 \mathrm{ml}$ aluminium angle rotor of an MSE Superspeed 65 ultracentrifuge, the rough endoplasmic reticulum fraction was obtained as a pellet at the bottom of the tube. The smooth endoplasmic reticulum fraction at the interface between the two sucrose layers was collected with a Pasteur pipette, diluted with $0.25 \mathrm{M}$-sucrose in water and pelleted by centrifugation at $105000 \mathrm{~g}$ for $1 \mathrm{~h}$.

\section{Assay of markers for subcellular fractions}

Protein assay. Protein was determined by the method of Lowry et al. (1951) with bovine serum albumin as standard.

Nucleic acid assays. DNA was determined by the method of Burton (1956), and RNA was determined by the method of Munro \& Fleck (1966).

Enzyme marker assays. Each assay was conducted under optimum conditions, and under which product formation was proportional to time of incubation and to the quantity of enzyme protein placed in the incubation mixture.

Acid phosphatase was assayed by the release of $p$-nitrophenol from $p$-nitrophenyl phosphate(Lansing et al., 1967). Succinic dehydrogenase was determined by the method of Morré (1971), and uridine diphosphatase was measured by the method of Plaut (1963).

\section{Determination of protocollagen hydroxylases}

Preparation of protocollagen. $\left[{ }^{3} \mathrm{H}\right]$ Proline-labelled protocollagen for use as substrate in the assay of protocollagen prolyl hydroxylase, was prepared according to the method of Jimenez et al. (1973). Freshly isolated embryonic chick tendon cells were incubated at $37^{\circ} \mathrm{C}$ in modified Krebs medium (Dehm \& Prockop $)\left(5 \times 10^{6}\right.$ cells $\left./ \mathrm{ml}\right)$ containing $0.3 \mathrm{~mm}$ $\alpha \alpha^{\prime}$-bipyridyl. After $30 \mathrm{~min} 25 \mu \mathrm{Ci}$ of $\left[{ }^{3} \mathrm{H}\right]$ proline $/ \mathrm{ml}$ was added and incubation continued for $3 \mathrm{~h}$. The cells were sedimented by centrifugation, the cell pellet was homogenized in $0.1 \mathrm{M}$-acetic acid and the extraction of protocollagen continued by stirring at $4^{\circ} \mathrm{C}$ for $18 \mathrm{~h}$. The extract was centrifuged at $21000 \mathrm{~g}$ for $30 \mathrm{~min}$ and the supernatant extensively dialysed against $0.1 \mathrm{M}$-acetic acid at $4^{\circ} \mathrm{C}$ before freeze-drying. The partially purified $\left[{ }^{3} \mathrm{H}\right]$ proline-labelled protocollagen was dissolved in $0.01 \mathrm{M}$-Tris- $\mathrm{HCl}$ buffer, $\mathrm{pH} 7.8$, at $4^{\circ} \mathrm{C}$ containing $0.2 \mathrm{M}-\mathrm{NaCl}$ and $0.2 \mathrm{M}$-glycine, heated to $100^{\circ} \mathrm{C}$ for $10 \mathrm{~min}$, then rapidly frozen and stored at $-20^{\circ} \mathrm{C}$.

$\left[{ }^{3} \mathrm{H}\right] \mathrm{L}$ ysine-labelled protocollagen was prepared in 
an identical manner by the incubation of tendon cells with $\alpha \alpha^{\prime}$-bipyridyl in medium containing $25 \mu \mathrm{Ci}$ of $\left[4,5-{ }^{3} \mathrm{H}\right]$ lysine $/ \mathrm{ml}$ of medium.

Protocollagen prolyl hydroxylase assay. Enzyme activity in the subcellular fractions was assayed with $\left[{ }^{3} \mathrm{H}\right]$ proline-labelled protocollagen as substrate and the amount of $\left[{ }^{3} \mathrm{H}\right]$ hydroxyproline synthesized was measured with a specific radiochemical assay (Juva \& Prockop, 1966). The pelletted subcellular fractions, obtained as described above, were resuspended in $1 \mathrm{ml}$ of $0.01 \mathrm{M}$-Tris- $\mathrm{HCl}$ buffer containing $0.2 \mathrm{M}-\mathrm{NaCl}$ and $0.2 \mathrm{M}$-glycine. The proteins of the cytosol fraction, including any prolyl hydroxylase, were precipitated by the addition of solid $\left(\mathrm{NH}_{4}\right)_{2} \mathrm{SO}_{4}$ to $65 \%$ saturation (Berg \& Prockop, 1973), and then sedimented by centrifugation at $21000 \mathrm{~g}$ for $20 \mathrm{~min}$. This cytosol fraction was also suspended in $1 \mathrm{ml}$ of $0.01 \mathrm{M}$-Tris- $\mathrm{HCl}$ buffer containing $0.2 \mathrm{M}-\mathrm{NaCl}$ and $0.2 \mathrm{M}$-glycine. Portions $(0.1 \mathrm{ml})$ from each subcellular suspension were taken for protein assay. The remainder of each fraction was incorporated into the reaction mixture of the enzyme assay which was carried out in a final volume of $2 \mathrm{ml}$ which included $0.2 \mathrm{ml}$ of substrate containing 50000 c.p.m. of $\left[{ }^{3} \mathrm{H}\right]$ proline, bovine serum albumin $(2 \mathrm{mg} / \mathrm{ml})$, catalase $(0.1 \mathrm{mg} / \mathrm{ml}), 0.05 \mathrm{mM}^{-} \mathrm{FeSO}_{4}$, $0.1 \mathrm{~mm}$-dithiothreitol, $2 \mathrm{~mm}$-ascorbate, $0.5 \mathrm{~mm}$ - $\alpha$-oxoglutaric acid and 0.05M-Tris-HCl buffer, $\mathrm{pH} 7.8$ (Halme et al., 1970). Unless otherwise indicated the reaction mixture also contained $0.1 \%$ Triton $\mathrm{X}-100$. The sample was incubated at $37^{\circ} \mathrm{C}$ for $1 \mathrm{~h}$ and then hydrolysed in $6 \mathrm{M}-\mathrm{HCl}$ at $110^{\circ} \mathrm{C}$ for $24 \mathrm{~h}$. The hydrolysed sample was evaporated to dryness and assayed directly for $\left[{ }^{3} \mathrm{H}\right]$ hydroxyproline (Juva \& Prockop, 1966).

Protocollagen lysyl hydroxylase assay. Enzyme activity in the subcellular fractions was assayed with $\left[{ }^{3} \mathrm{H}\right]$ lysine-labelled protocollagen as substrate and the formation of $\left[{ }^{3} \mathrm{H}\right]$ hydroxylysine was assayed by measurement of the exchange of ${ }^{3} \mathrm{H}$ with water after hydroxylation (Miller, 1972). Details of the reaction mixture for the enzyme assay are identical with those for protocollagen prolyl hydroxylase with the ex- ception of the $0.2 \mathrm{ml}$ of substrate which contained 100000 c.p.m. of $\left[{ }^{3} \mathrm{H}\right]$ lysine-labelled protocollagen. The sample was incubated for $1 \mathrm{~h}$ at $37^{\circ} \mathrm{C}$ and then $0.2 \mathrm{ml}$ of $50 \%$ trichloroacetic acid added to stop the reaction and precipitate the proteins. The protein precipitate was removed by centrifugation and the supernatant was distilled to permit collection of ${ }^{3} \mathrm{H}_{2} \mathrm{O}$, a sample $(1 \mathrm{ml})$ of which was counted with $10 \mathrm{ml}$ of scintillation fluid comprising 2 vol. of scintillant [5 $\mathrm{g}$ of 2,5-diphenyloxazole and $0.3 \mathrm{~g}$ of 1,4-bis(4-methyl-5-phenyloxazol-2-yl)benzene in 1 litre of toluene] and 1 vol. of Triton X-100.

\section{Results}

Characterization of tendon cell fractions obtained by differential centrifugation

Tendon cells were homogenized and fractionated by differential centrifugation as described above, and the fractions were assayed for DNA, RNA, protein and appropriate marker enzymes. The absolute recoveries of these markers and their distributions between the subcellular fractions are reported in Table 1. To permit comparison between one marker and another, their distributions among subcellular fractions have been corrected to $100 \%$ recovery and are presented relative to the crude homogenate in Fig. 1.

The nuclear fraction $(\mathrm{N})$ contained the bulk of the DNA and the mitochondrial fraction (ML) contained almost all the succinic dehydrogenase. In addition this ML fraction contained approx. $70 \%$ of total acid phosphatase activity indicating that the lysosomes were sedimenting predominantly with this fraction. That fraction $M$ represented the bulk of the microsomal fraction is demonstrated by the fact that uridine diphosphatase activity is concentrated in this fraction. It should be noted that contamination of this microsomal fraction with DNA, succinic dehydrogenase and acid phosphatase is minimal and further evidence of its relative purity was obtained by electron microscopy (Plate 1).

\section{Table 1. Fractionation of tendon cell homogenates by differential centrifugation}

The tendon cell homogenate and subcellular fractions were assayed for DNA, RNA, protein and appropriate enzyme markers as described in the text. The distribution of each marker in the various fractions is presented as a percentage relative to the concentration in the crude homogenate.

\begin{tabular}{lcccccc}
\multicolumn{1}{c}{ Fraction } & $\begin{array}{c}\text { DNA } \\
(\%)\end{array}$ & $\begin{array}{c}\text { RNA } \\
(\%)\end{array}$ & $\begin{array}{c}\text { Succinic } \\
\text { dehydrogenase } \\
(\%)\end{array}$ & $\begin{array}{c}\text { Acid } \\
\text { phosphatase } \\
(\%)\end{array}$ & $\begin{array}{c}\text { Uridine } \\
\text { diphosphatase } \\
(\%)\end{array}$ & $\begin{array}{c}\text { Protein } \\
(\%)\end{array}$ \\
Nuclei (N) & 92.1 & 17.2 & 9.6 & 5.7 & 7.3 & 16.8 \\
Mitochondria (ML) & 3.9 & 25.1 & 84.5 & 72.1 & 20.3 & 20.2 \\
Microsomes (M) & 2.7 & 43.7 & 3.7 & 10.8 & 67.9 & 18.8 \\
Cytosol (C) & 1.1 & 11.6 & 3.4 & 11.4 & 3.6 & 30.1 \\
Recovery & 99.8 & 97.6 & 101.2 & 99.0 & 99.1 & 85.9
\end{tabular}

Vol. 144 

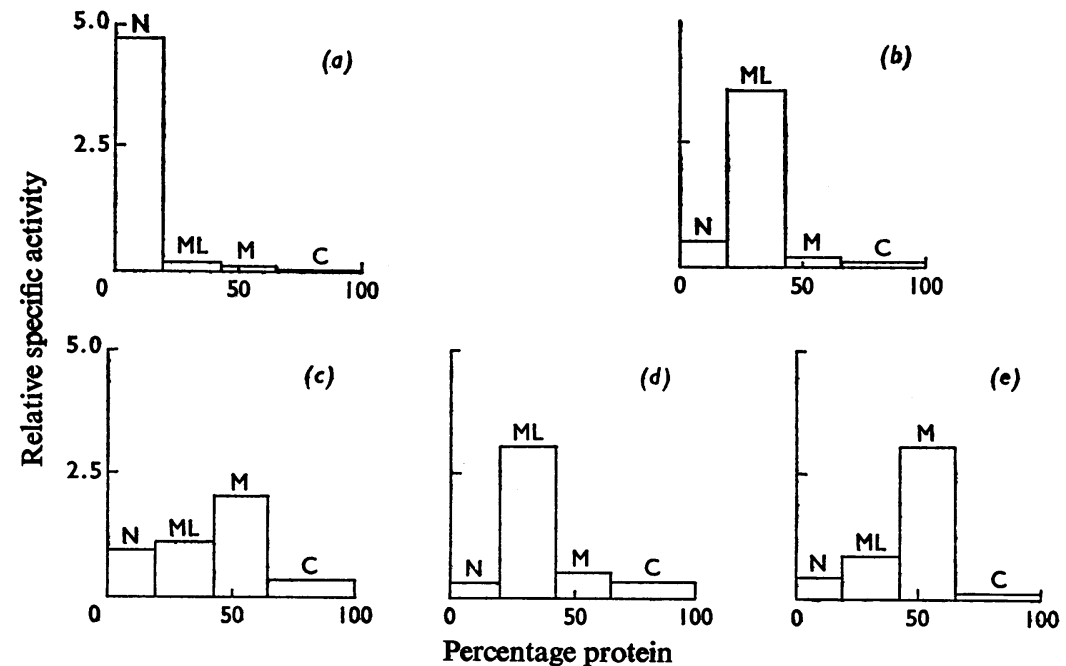

Fig. 1. Distribution of markers in tendon cell fractions obtained by differential centrifugation

Each of the fractions was assayed for the indicated enzyme activities, RNA, DNA and protein. The subcellular fractions are: $\mathrm{N}$, nuclei; ML, mitochondria and lysosomes; M, microsomes; C, cytosol. The markers are: (a) DNA; (b) succinic dehydrogenase; (c) RNA; (d) acid phosphatase; (e) uridine diphosphatase.

Table 2. Distribution of protein and RNA in submicrosomal fractions of tendon and cartilage cells

Tendon and cartilage cells were homogenized in $0.25 \mathrm{M}$ sucrose and fractionated according to the method of Dallner (1963). Fractions were assayed for RNA and protein and values are given relative to those obtained with the crude homogenate.

\begin{tabular}{|c|c|c|c|c|}
\hline & \multicolumn{2}{|c|}{ Tendon } & \multicolumn{2}{|c|}{ Cartilage } \\
\hline & $\begin{array}{l}\text { Protein } \\
(\%)\end{array}$ & $\begin{array}{c}\text { RNA } \\
(\%)\end{array}$ & $\begin{array}{l}\text { Protein } \\
(\%)\end{array}$ & $\begin{array}{c}\text { RNA } \\
(\%)\end{array}$ \\
\hline Homogenate & 100 & 100 & 100 & 100 \\
\hline Nuclei & 30.1 & 31.1 & 31.6 & 32.7 \\
\hline Mitochondria & 24.2 & 15.2 & 25.1 & 16.1 \\
\hline $\begin{array}{l}\text { Rough endoplasmic } \\
\text { reticulum }\end{array}$ & 5.4 & 27.2 & 4.8 & 25.8 \\
\hline $\begin{array}{l}\text { Smooth endoplasmic } \\
\text { reticulum }\end{array}$ & 4.9 & 3.1 & 5.0 & 3.7 \\
\hline Cytosol & 37.1 & 26.8 & 33.5 & 20.7 \\
\hline
\end{tabular}

Characterization of fractions of rough endoplasmic reticulum and smooth endoplasmic reticulum from tendon and cartilage cells

The isolation of rough and smooth endoplasmic reticulum fractions by the method of Dallner (1963) requires that homogenization of cells be conducted in a medium free of $\mathbf{M g}^{2+}$ ions which would otherwise interfere with the separation of these fractions. Accordingly, these fractionation conditions result in a somewhat different distribution of RNA and protein (Table 2) from that obtained by differential centrifugation (Table 1). The results shown in Table 2 are comparable with data obtained for other tissues, e.g. liver (Dallner, 1963; Schachter et al., 1970) and kidney (Goldstone et al., 1973; Goldstone \& Koenig, 1973), and demonstrate that the fractionation on discontinuous sucrose density gradients yields fractions of rough and smooth endoplasmic reticulum representative of these submicrosomal regions of the cells.

Electron-microscopic studies of these fractions revealed the characteristic morphology of ribosomestudded vesicles and smooth vesicles in the respective fractions (Plates $2 a, 2 b$ and $2 c$ ).

Influence of Triton $X-100$ on activity of protocollagen prolyl hydroxylase and protocollagen lysyl hydroxylase in homogenates of tendon and cartilage cells

The use of Triton X-100 in investigations of membrane-bound intracellular enzymes has been reported in several studies (Bouchilloux et al., 1969; Hagopian \& Eylar, 1969; Molnar et al., 1969; Bosmann, 1970; Schachter et al., 1970; Richard et al., 1972). Because data on the subcellular location of protocollagen prolyl hydroxylase are conflicting (Peterkofsky \& Udenfriend, 1965; Kivirikko \& Prockop, 1967) and because protocollagen lysyl hydroxylase does not appear to be completely soluble (Kivirikko \& Prockop, 1972), the influence of Triton X-100 on the 


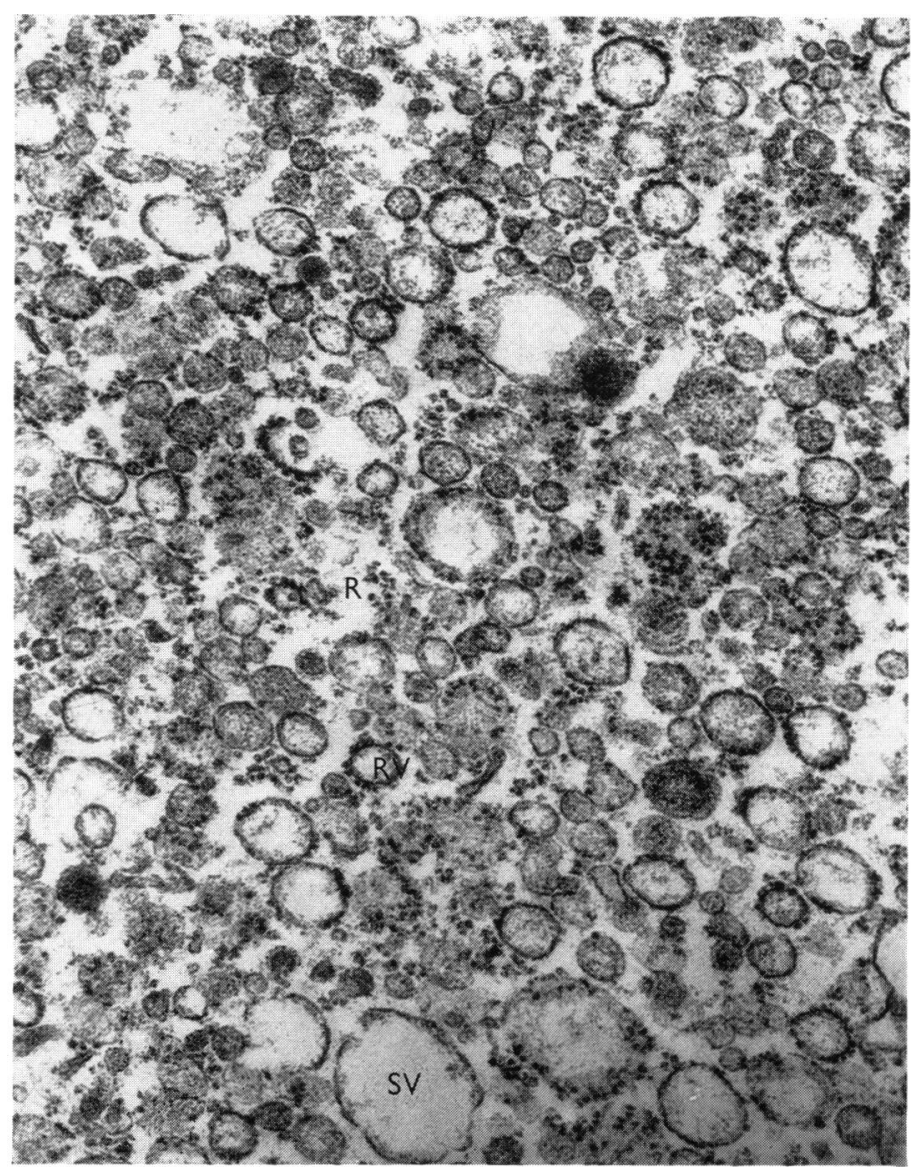

\section{EXPLANATION OF PLATE I}

Electron micrograph of microsomal fraction isolated from tendon cells

The microsomal pellet obtained as described in the text was fixed with buffered glutaraldehyde solution, post-fixed with $1 \%$ ( $v / v) \mathrm{OsO}_{4}$ and dehydrated in a graded ethanol series and propylene oxide. The pellet was embedded in Araldite, and ultrathin sections, stained with uranyl acetate $(0.2 \%)$ and lead citrate $(0.02 \%)$, were examined in a Philips EM 201 electron microscope. The pellet is rich in ribosomes which are present as membrane-free clusters $(R)$ and in association with membranous vesicles (RV). Smooth membranous vesicles (SV) are also evident in the pellet. Note the absence of any mitochondrial or lysosomal contaminants (magnification $\times 33000$ ). 

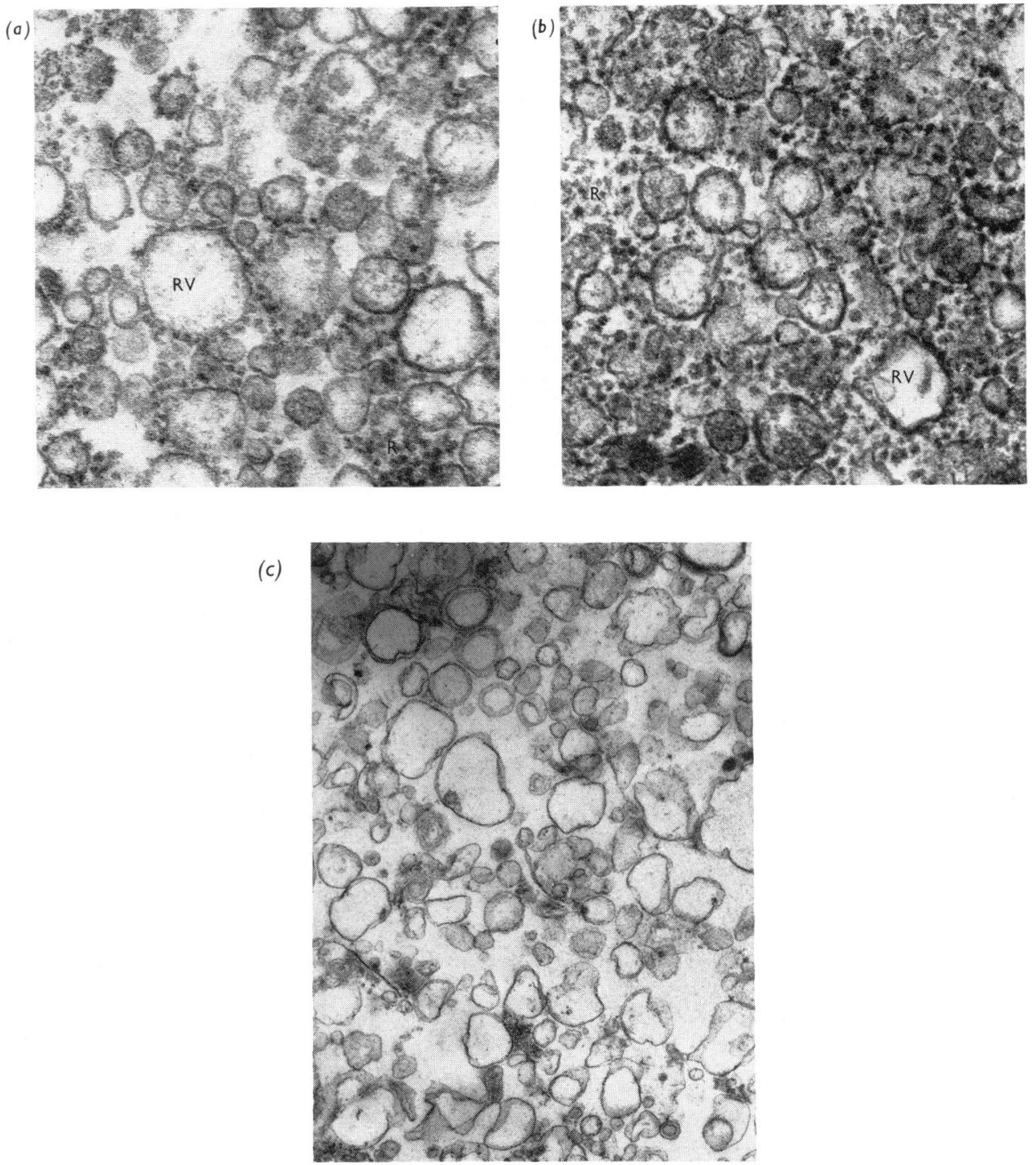

\section{EXPLANATION OF PLATE 2}

Electron micrographs of submicrosomal fractions isolated from tendon cells

Fractions of rough endoplasmic reticulum and smooth endoplasmic reticulum were obtained by discontinuous sucrosedensity-gradient centrifugation as described in the text. The pellets were prepared for electron microscopy as described in the legend to Plate 1. ( $a$ and $b$ ) The rough endoplasmic reticulum fraction comprises ribosome-studded vesicles (RV) and free ribosomes $(\mathrm{R})$ (magnification $\times 50000$ ). (c) The smooth endoplasmic reticulum fraction comprises smooth membranous vesicles which are devoid of attached ribosomes (magnification $\times 33000$ ). 


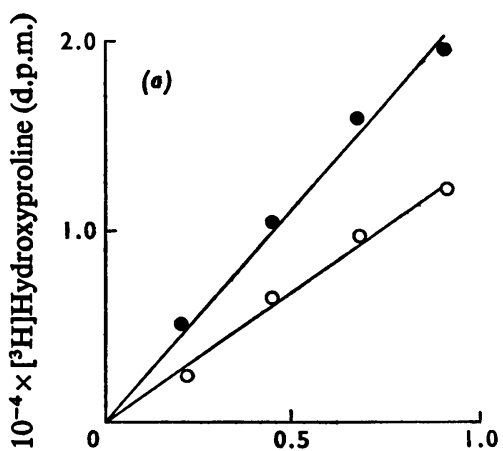

Protein (mg)

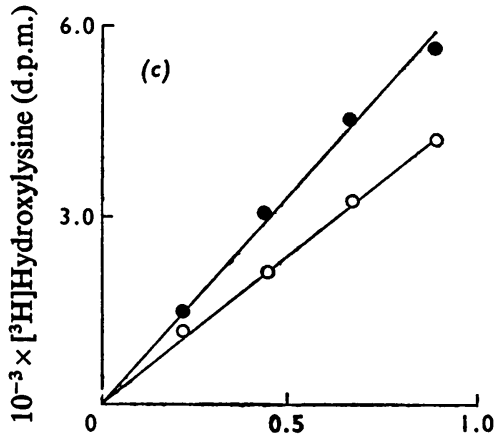

Protein (mg)
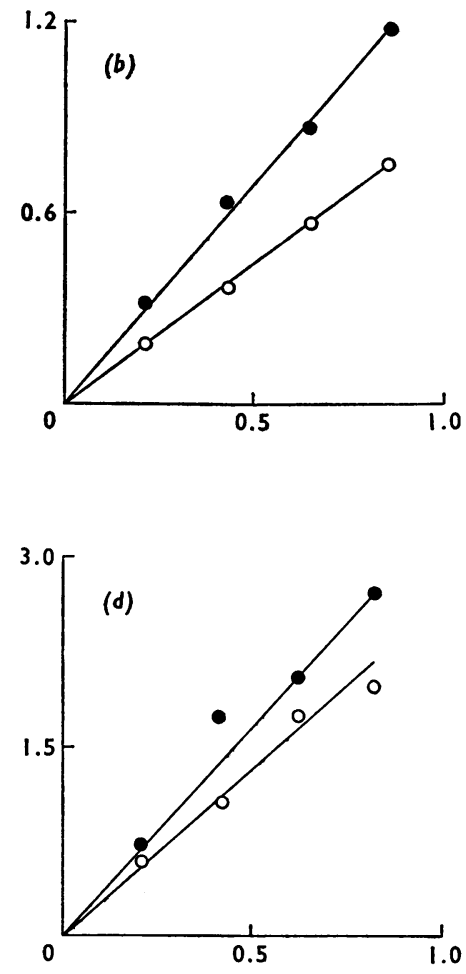

Fig. 2. Effect of Triton $X-100$ on activities of protocollagen prolyl hydroxylase and protocollagen lysyl hydroxylase in homogenates of tendon and cartilage cells

Cells were homogenized in $0.25 \mathrm{M}$-sucrose in Tris- $\mathrm{KCl}-\mathrm{MgCl}_{2}$ buffer, the homogenate was diluted with buffer to the equivalent of approx. $2.5 \times 10^{6}$ cells $/ \mathrm{ml}$ and samples of $0.2,0.4,0.6$ and $0.8 \mathrm{ml}$ were assayed for prolyl and lysyl hydroxylase as described in the text. $O$, In the presence of $0.1 \%$ Triton X-100; $O$, in the absence of detergent. (a) Prolyl hydroxylase activity in an homogenate of tendon cells; (b) prolyl hydroxylase activity in an homogenate of cartilage cells; (c) lysyl hydroxylase activity in an homogenate of tendon cells; $(d)$ lysyl hydroxylase activity in an homogenate of cartilage cells.

activities of these enzymes in cell homogenates was investigated.

In both tendon and cartilage cell homogenates prolyl hydroxylase activities were increased to values $60 \%$ above controls (Figs. $2 a$ and $2 b$ ) when $0.1 \%$ Triton X-100 was included in the assay incubation mixture. The detergent was also found to stimulate lysyl hydroxylase activity in both cell homogenates but the degree of enhancement was lower than that observed for prolyl hydroxylase, being $\mathbf{4 0}$ and $28 \%$ above controls in tendon and cartilage cell homogenates respectively.

It should be noted that the increases in enzyme activities in the tendon and cartilage cell homogenates are slightly lower than those reported for prolyl hydroxylase in liver and kidney homogenates (Guzman \& Cutroneo, 1973) but direct comparison is not meaningful because of probable differences in the relative proportions of protein and detergent.
Distribution of protocollagen prolyl hydroxylase and protocollagen lysyl hydroxylase in subcellular fractions of tendon and cartilage cells

Subcellular fractions obtained by the two centrifugation schemes described above were assayed for protein content and both prolyl and lysyl hydroxylase activities. The results shown in Table 3 demonstrate that in both tendon and cartilage cells the distribution patterns of prolyl hydroxylase are almost identical, the major portion of this enzyme activity being detected in the microsomal fractions. In further experiments the prolyl hydroxylase was found to be present predominantly in the rough endoplasmic reticulum fractions obtained from both cell types. The specific activities of the rough endoplasmic reticulum fractions are lower than that of the microsomal fractions obtained by differential centrifugation. This latter observation may be explained by gradual loss of 

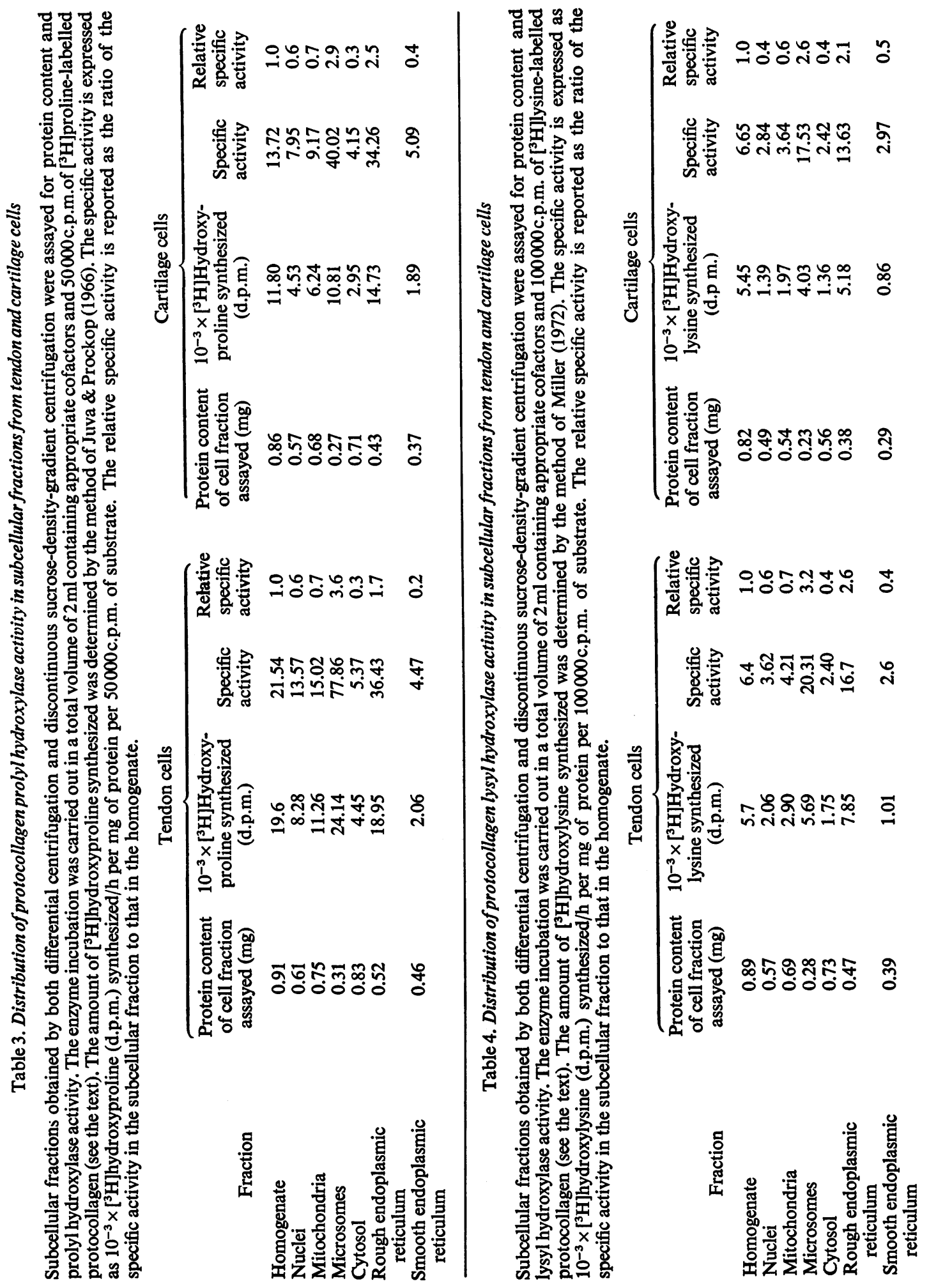
activity owing to denaturation during the discontinuous sucrose-density-gradient-centrifugation procedure and similar losses of activity of a variety of enzymes have been reported by other workers (Schachter et al., 1970).

Table 4 reports data obtained for the distribution of lysyl hydroxylase in subcellular fractions from both tendon and cartilage cells. The results show that the two hydroxylases are remarkably similar in their distribution patterns and suggest that lysyl hydroxylase is also associated with the rough endoplasmic reticulum.

\section{Discussion}

Collagen is the major protein synthesized and secreted by both embryonic chick tendon and cartilage cells (Dehm \& Prockop, 1972, 1973) and the digestion of the extracellular matrix by collagenase and trypsin (Dehm \& Prockop, 1971) removes one of the major obstacles to the successful fractionation of fibroblasts. By taking appropriate precautions (Avis, 1972) we have successfully homogenized and fractionated embryonic chick tendon fibroblasts, and the data presented in Fig. 1 and Tables 1 and 2, indicate that the purities of the subcellular fractions obtained are comparable with results obtained in the fractionation of other tissues (Dallner, 1963; Schachter et al., 1970; Goldstone et al., 1973; Goldstone \& Koenig, 1973). No detailed characterization of the cartilage subcellular fractions was carried out but the data in Table 2 and the results relating to the location of the hydroxylases (Tables 3 and 4) would appear to indicate that conditions developed for tendon cell homogenization could be satisfactorily applied to cartilage cells. The ability to fractionate both cell types thus makes possible an investigation of the intracellular location of some of the post-translational events in collagen biosynthesis.

In common with other secreted proteins, procollagen is synthesized on membrane-bound polyribosomes (Diegelmann et al., 1973; Harwood et al., 1973, 1974a). Also it has been demonstrated that interchain disulphide bonding of tendon procollagen polypeptides occurs in the rough endoplasmic reticulum soon after release of the completed chains from the polyribosomes (Harwood et al., 1973). That the rough endoplasmic reticulum is also the site of the hydroxylation of peptidyl proline is suggested by several reports of the presence of hydroxyproline in nascent collagen polypeptides (Fernandez-Madrid, 1970; Miller \& Udenfriend, 1970; Lazarides et al., 1971; Harwood et al., 1973, 1974a; Uitto \& Prockop, 1974). More recent studies using short-term $\left[{ }^{14} \mathrm{C}\right]-$ lysine labelling of tendon cells (Uitto \& Prockop, 1974) and cartilage cells (R. Harwood, A. K. Bhalla, M.E. Grant \& D. S. Jackson, unpublished work) have indicated that some hydroxylation of lysine also occurs in nascent procollagen peptides. These observations imply a close association of the hydroxylases with membrane-ribosome complexes but do not exclude the possibility of hydroxylation being completed at another intracellular site.

Preliminary evidence that both the prolyl and lysyl hydroxylases in tendon and cartilage cells are membrane-bound was obtained by studies of cell homogenates assayed for these enzymes in the presence and absence of $0.1 \%$ Triton X-100. A significant stimulation of enzyme activity was found to occur in the presence of the detergent but lysyl hydroxylase activity was not stimulated to quite the same extent as prolyl hydroxylase activity. Assays of the subcellular fractions for the hydroxylases indicated that only a small percentage of the total activities was present in the cytosol fractions. Most of the activities of both prolyl and lysyl hydroxylases was associated with the microsomal fractions. Subsequent fractionation of the microsomal fraction by discontinuous gradient centrifugation revealed that both protocollagen prolyl hydroxylase and protocollagen lysyl hydroxylase are located almost exclusively in the rough endoplasmic reticulum fraction of both tendon and cartilage cells and therefore we suggest that hydroxylation occurs predominantly on the rough endoplasmic reticulum in these cells.

In a recent study of collagen biosynthesis using a cell-free system it was reported that prolyl hydroxylase activity was bound to a microsomal fraction capable of directing the synthesis of collagen polypeptides (Diegelmann et al., 1973). Our results are in accordance with this finding but neither study enables one to ascertain whether the hydroxylases are located on the ribosomal or non-ribosomal sides of the membrane. However, evidence that prolyl hydroxylase is localized within the cisternae of the rough endoplasmic reticulum has come from a recent report in which ferritin-labelled antibodies against prolyl hydroxylase were used (Olsen et al., 1973).

The successful fractionation of matrix-free fibroblasts has permitted the localization of the two hydroxylases which effect the first post-translational modifications of the procollagen polypeptides and now makes possible further studies to determine the route of procollagen secretion.

Mr. Ashok Bhalla participated in the analysis of the cartilage subcellular fractions and Dr. J. S. Dixon, Department of Anatomy, University of Manchester, assisted in preparing the electron micrographs. We acknowledge the technical assistance of Mr. A. Colwell and the financial support of the Science Research Council.

\section{References}

Avis, P. J. G. (1972) in Subcellular Components (Birnie, G. D., ed.), 2nd edn., pp. 1-13, Butterworths, London Berg, R. A. \& Prockop, D. J. (1973) J. Biol. Chem. 248, 1175-1182 
Bosmann, H. B. (1970) FEBS Lett. 8, 29-32

Bouchilloux, S., Ferrand, M., Gregoire, J. \& Chabaud, 0. (1969) Biochem. Biophys. Res. Commun. 37, 538-544

Burton, K. (1956) Biochem. J. 62, 315-323

Dallner, G. (1963) Acta Pathol. Microbiol. Scand. Suppl. 166, 1-94

Dehm, P. \& Prockop, D. J. (1971) Biochim. Biophys. Acta 240, 358-369

Dehm, P. \& Prockop, D. J. (1972) Biochim. Biophys. Acta 264, 375-382

Dehm, P. \& Prockop, D. J. (1973) Eur. J. Biochem. 35, 159-166

Diegelmann, R. F., Bernstein, L. \& Peterkofsky, B. (1973) J. Biol. Chem. 248, 6514-6521

Fernandez-Madrid, F. (1970) Clin. Orthop. Rel. Res. 68, 163-181

Grant, M. E. \& Prockop, D. J. (1972a) N. Engl. J. Med. 286, 194-199

Grant, M. E. \& Prockop, D. J. (1972b) N. Engl. J. Med. 286, 242-249

Grant, M. E. \& Prockop, D. J. (1972c) N. Engl. J. Med. 286, 291-300

Goldstone, A. \& Koenig, H. (1973) Biochem. J. 132, 267-282

Goldstone, A., Koenig, H., Nayyar, R., Hughes, C. \& Lu, C. Y. (1973) Biochem. J. 132, 259-266

Guzman, N. A. \& Cutroneo, K. R. (1973) Biochem. Biophys. Res. Commun. 52, 1263-1270

Hagopian, A. \& Eylar, E. H. (1969) Arch. Biochem. Biophys. 129, 515-524

Halme, J., Kivirikko, K. I. \& Simons, K. (1970) Biochim. Biophys. Acta 198, 460-470

Harwood, R., Grant, M. E. \& Jackson, D. S. (1973) Biochem. Biophys. Res. Commun. 55, 1188-1196

Harwood, R., Connolly, A. D., Grant, M. E. \& Jackson, D. S. (1974a) FEBS Lett. 41, 85-88

Harwood, R., Grant, M. E. \& Jackson, D. S. (1974b) Biochem. Soc. Trans. 2, 626-627
Jimenez, S. A., Dehm, P., Olsen, B. R. \& Prockop, D. J. (1973) J. Biol. Chem. 248, 720-729

Juva, K. \& Prockop, D. J. (1966) Anal. Biochem. 15, 77-83

Kivirikko, K. I. \& Prockop, D. J. (1967) Arch. Biochem. Biophys. 118, 611-618

Kivirikko, K. I. \& Prockop, D. J. (1972) Biochim. Biophys. Acta 258, 366-379

Lansing, A. I., Belkhode, M. L., Lynch, W. E. \& Lieberman, I. (1967) J. Biol. Chem. 242, 1772-1775

Lazarides, E. L., Lukens, L. N. \& Infante, A. A. (1971) J. Mol. Biol. 58, 831-846

Lowry, O. H., Rosebrough, N. J., Farr, A. L. \& Randall, R. J. (1951) J. Biol. Chem. 193, 265-275

Miller, R. L. (1972) Anal. Biochem. 45, 202-210

Miller, R. L. \& Udenfriend, S. (1970) Arch. Biochem. Biophys. 139, 104-113

Molnar, J., Chao, H. \& Markovic, G. (1969) Arch. Biochem. Biophys. 134, 533-538

Morré, D. J. (1971) Methods Enzymol. 22, 130-148

Munro, H. N. \& Fleck, A. (1966) Analyst (London) 91, 78-88

Olsen, B. R., Berg, R. A., Kishida, Y. \& Prockop, D. J. (1973) Science 182, 825-827

Peterkofsky, B. \& Udenfriend, S. (1965) Proc. Nat. Acad. Sci. U.S. 53, 335-342

Plaut, G. W. E. (1963) Methods Enzymol. 6, 231-236

Richard, M., Broquet, P. \& Louisot, P. (1972) J. Mol. Cell. Cardiol. 4, 465-475

Schachter, H., Jabbal, I., Hudgin, R. L., Pinteric, L., McGuire, E. J. \& Roseman, S. (1970) J. Biol. Chem. 245, 1090-1100

Schofield, J. D. \& Prockop, D. J. (1973) Clin. Orthop. Rel. Res. 97, 175-195

Uitto, J. \& Prockop, D. J. (1974) Arch. Biochem. Biophys. in the press

Wünsch, E. \& Heidrich, H.-G. (1963) Hoppe-Seyler's Z. Physiol. Chem. 333, 149-151 